This is the final peer-reviewed accepted manuscript of:

Solaroli, M. The Rules of a Middle-Brow Art: Digital Production and Cultural Consecration in the Global Field of Professional Photojournalism. Poetics 2016, 59, 50-66. 10.1016/j.poetic.2016.09.001.

The final published version is available online at:

https://doi.org/10.1016/j.poetic.2016.09.001

Rights / License:

The terms and conditions for the reuse of this version of the manuscript are specified in the publishing policy. For all terms of use and more information see the publisher's website.

This item was downloaded from IRIS Università di Bologna (https://cris.unibo.it/)

When citing, please refer to the published version. 


\title{
The rules of a middle-brow art Digital production and cultural consecration in the global field of professional photojournalism
}

***Accepted final version, post peer-review. To be published in Poetics (Elsevier), 59, 2016***

\begin{abstract}
Drawing on Bourdieu's work on photography, field-theory, and recent research on global journalism and digital photography, this paper advances the framework of the "global photojournalistic field", and empirically focuses on the consecration of a transnational elite of professional photojournalists over the last two decades. It investigates such a process as a prism through which to understand major changes that have been investing the field of professional photojournalism and the wider field of photography since the early 2000s, e.g. the increasingly blurring boundaries between professional and citizen photojournalism, and between news photography and fine-art photography. The paper draws on archive analysis of major international newsmagazines and qualitative interviews with internationally renowned photojournalists, photo-editors, and directors of global news photo agencies. It examines specific news photographs by tracing their aesthetic shapes back to field-dynamics, thus unveiling the "rules of the field" that govern the practices of production and the symbolic struggles for distinction, authorship, boundary-making, and power within global photojournalism. Finally, it advances the thesis of an externally favoured process of reciprocal influence between the consecration of a group of professional photojournalists in the global field and the increasing position of news photography in the hierarchy of cultural legitimacies of late-modern society.
\end{abstract}

Keywords

Bourdieu; global field; photojournalism; photography; consecration; Magnum Photos.

Is it possible and necessary for the practice of photography and the meaning of the photographic image to provide material for sociology?

Bourdieu 1990, 1

\section{Introduction: Shifting professional practices, symbolic boundaries and cultural hierarchies}

As an increasing, yet fragmented, literature has shown, the cultural field of professional photojournalism is one of the least codified and least capable of completely defining its internal social actors, practices, rules, and hierarchies, as well as its external relationships with other close fields such as journalism, photography, arts, and technology (Bourdieu 1965; Boltanski 1965; Hall 1973; Rosenblum 1978; Webster 1980; Schwartz 1990; Barnhurst 1994; Becker 1995; Zelizer 2005; Brennen 2010; Solaroli 2015; Hariman and Lucaites 2016). Moreover, professional photojournalism is undergoing huge mutations, caused by interweaving technological, social, and economic processes, such as the digitalization of visual news flows, the diffusion of nonprofessional practices of photographic production, as well as the global financial crisis - which has exacerbated the structural deficiencies, further reducing the editorial market for professional photojournalists. Scholars increasingly argue that the diffusion of new digital technologies and new practices of news production (e.g. the so-called phenomena of "digital revolution" and "citizen photojournalism") poses a deep challenge to the already scarcely institutionalized and legitimated field of professional photojournalism (Andén-Papadopoulos and Pantti 2011; Allan 2013; Allan and Patrick 2013; Ritchin 2013). 
However, notwithstanding the frequency with which the refrain of the decline of professional photojournalism is usually heard, over the last fifteen years a restricted but increasingly influential elite of mainly European photojournalists has acquired impressive international consecration, by entering the most famous authorial photo agencies, covering major news events on assignment for mainstream international newsmagazines, repeatedly winning the most prestigious professional awards, and producing images that eventually turn out to play a key role in contemporary global visual culture.

How was that possible? In other words, how did such a striking process of consecration of a group of historically de-legitimated and marginal cultural producers take place, in a moment of overall professional decline? How and why did this peculiar transnational configuration of the photojournalistic field emerge? How does it shape the visual-representational forms of world news stories? And what might it comparatively reveal of different national professional traditions of the photojournalistic practice within the rapidly shifting and increasingly global-digital ecology of competition?

This paper investigates the historical formation as well as the struggle for distinction and symbolic power - that is, for authorship and consecration - of such a transnational elite in the global field of professional photojournalism. It looks at such a process as a prism through which to understand a variety of innovations and tensions that have been investing the field of professional photojournalism as well as the wider field of photography over the last two decades - e.g. the increasingly blurring boundaries between professional and citizen photojournalism, as well as between news photography and fine art photography.

The paper is divided into three sections. In the first one, after a review of the literature on news photography, the paper develops the analytical-conceptual framework of the "global field" of photojournalism. Drawing on Bourdieu's (1965) classic analysis of photography as a middle-brow art, and more recent neo-Bourdieusian research on the sociology of journalism (Bourdieu 1994; 2000; Benson and Neveu 2005; Benson 1999; 2004; 2013), it creatively applies the model of the cultural field (Bourdieu 1983; 1985; 1992; 1993) to the case of photojournalism and, in so doing, it re-scales field-theory within the "global/transnational" focus of contemporary media and journalism research (Cottle 2009; Berglez 2013). In the second section, the paper offers a field analysis of the recently consecrated transnational elite of photojournalists, empirically focusing on a few news photographs produced by actors differently positioned in the global field, and tracing their aesthetic shapes back to field dynamics - in particular, to their producers' symbolic struggles for distinction and power. Finally, in the last section, the paper advances the thesis of an externally favoured process of reciprocal influence between the internal consecration of a specific group of photojournalists as cultural producers in the global professional field and the consecration of photography as a genre in the hierarchy of cultural legitimacy. It shows how, in a productive circle of field effects, photojournalists struggling for power adjusted the existing standards of practice to the ongoing changes by producing innovative photojournalistic styles that could affirm their distinctive status of photojournalistic authors, with a strategy of field position-taking that led them increasingly closer to the field of fine art. In conclusion, the paper suggests that such a process was partly determined by - and closely intertwined with - the emergence of non-professional producers in the field, and it shows that in turn it eventually strengthened the symbolic boundaries not only among different professional producers in the field but also, relevantly, between the professional and the non-professional (citizen) producers of news photography.

\section{Research data and methods}

This paper is based on an archive analysis of the photojournalistic coverage of major news events on nine mainstream international newsmagazines over the last twenty-five years (1990-2015) ${ }^{1}$, as

\footnotetext{
${ }^{1}$ Time; Newsweek; The New York Times Magazine; US News and World Report; National Geographic (US); Paris Match (France); Stern (Germany); L’Espresso; Panorama (Italy).
} 
well as on forty in-depth interviews with internationally renowned photojournalists, photo-editors working for major newsmagazines, jurors of global press photo prizes, and directors of global photo agencies. $^{2}$

Every news story of international relevance that was photo-journalistically covered by at least two of the nine newsmagazines was included in the research set. The collected visual content for each news story was then analyzed qualitatively and comparatively, across the different newsmagazines, by focusing in particular on the identification of mainstream and dominant visualrepresentational forms vis-à-vis emerging trends of innovative photo-journalistic styles. The comparative archive analysis also allowed a first but only partial reconstruction of the main social networks and the wider structure of the professional field (in terms of names, roles, and positions of key actors and organizations).

The sample of interviewees was subsequently constructed by contacting most photojournalists whose photographs had been included in the research set, and - when their names were publicly available - the photo-editors who had assigned the photojournalists and then selected and published their photographs. The photojournalists and photo-editors were either contacted online or approached in person, mainly at various photo gallery exhibitions and news photo festivals in the US, France and Italy. The construction of the sample of interviewees was made possible in part also through snowball techniques, given the difficulty to reach elite (and often highly mobile) professionals, to identify the photo-editors with which they worked, and, more widely and relevantly, to map as precisely and completely as possible a professional field of visual cultural producers that remain quite dispersed and invisible - a methodological obstacle that, as the next pages will make clear, turns out to be also related to (and index of) the low degree of institutionalization of the field as a whole.

\section{Sociology of photojournalism and field-theory: new global conceptual frameworks}

As an object of theoretical and empirical inquiry, photojournalism has long constituted a paradoxical lacuna. In fact, newspapers and newsmagazines worldwide regularly turn over their column inches to professional - and, more recently, citizen - photographs. However, notwithstanding the pervasive circulation of images in the global news ecology, news photography has historically received scarce attention within the sociology of media, journalism and cultural production. As a whole, the available research results on the practices and forms of photojournalism offer at best a very fragmented scenario.

The reasons behind such a relative amount of empirical research and theoretical analysis can hardly be reconstructed. However, it is clear that since the late 1960s the literature on news-making and media framing has focused almost exclusively on verbal texts, without problematizing the role of photography on newspapers, or addressing it only through quite rare and mostly quantitative textual analyses (e.g. visual content analyses and visual framing analyses). No research has organically investigated the crucial relations between the social practices of cultural production (i.e. professional practices of visual news gathering, selection and publishing, which are embedded within - and at least partly determined by - configurations of power both in the newsrooms and in the wider professional field) and the form, style, and value of the final products, i.e. the news photographs.

In the 1960s and 1970s seminal research did initially undertake such a path, but it has not been systematically taken up since. For example, within the ground-breaking research on photography (and its position in the hierarchy of cultural legitimacies) led by Bourdieu (1965), Boltanski investigated the practices of production of professional French photojournalists working for the newspaper France-Soir and the newsmagazine Paris Match. Boltanski underlined that photojournalists had to face the fact that "the photographic document is naturally ambiguous: it can

\footnotetext{
${ }^{2}$ The 2-to-6-hour long interviews were carried out by the author between 2010 and 2016 in New York, London, Milan and Rome. They were conducted also through photo-elicitation techniques.
} 
be commented upon ... in different ways", therefore it was "impossible for the photojournalist to totally control an always fleeting product and to see it as his/her own", and thus photojournalists had "a sad consciousness of their own profession" (Boltanski 1965, 182-183; 191-192). ${ }^{3}$ A few years later, Hall (1973) similarly highlighted the heterogeneity of potential meanings of news photographs and the limited power of the photojournalists vis-a-vis the relevance of the photoeditors and the newsroom practices of selection and framing, in the UK; while, in the US, Rosenblum (1978) ethnographically showed that photographic practices were deeply influenced by organizational constraints, and that the "newspaper picture-making process" was "a highly complex, coordinated series of activities and communications that spreads out decision making over a considerable number of people ... [who] do not usually consult one another" (Rosenblum 1978, 54). More recently, Zelizer (2005, 173) critically argued that "though recognized at least in the popular imagination as powerful and authoritative, photographs remain a vehicle for news relays that is unaddressed by the community most relevant in determining their use - journalists", therefore, "how to use images in the news, how or whether to credit or caption them, how to affix them to the words at their side remain unanswered questions in the use of visuals in the news".

From a sociological perspective, the lack of standardization about how to use pictures in the press (even more than one hundred fifty years after their introduction), the marginalization of photography as a mode of news relay and its relegation to merely illustrative adjunct to written journalism can all be traced back to the very weak degree of institutional legitimation and cultural autonomy of photojournalism - especially if compared to written journalism (Zelizer 1995; Reich and Klein-Avraham 2014).

In this context, over the last decade, scholars have focused on the professional crisis of photojournalism caused by the so-called "digital revolution", which has allowed newsrooms worldwide to easily access vast photo archives online, and lay people to operate as potential producers of visual news - as demonstrated for example by the photos of the Abu Ghraib scandal, the London bombings, or the "Arab spring" collective protests - with considerably negative implications in terms of loss of salaried jobs and increased precariousness for professional photojournalists (Andén-Papadopoulos and Pantti 2011; Allan 2013; Allan and Patrick 2013; Pogliano 2015).

As a whole, the existing literature does not appear fully adequate to investigate the shifting practices of contemporary professional photojournalism and, specifically, to answer the questions of the struggle for distinction and consecration raised in the introduction. On this basis, drawing on the suggestion that "in order to make press photography into an autonomous sociological object, it is necessary to consider it as a cultural product, and to unveil the system of rules which governs its production ... how they are acted upon, how they are embodied in the conducts, how they regulate the professional life of particular professional groups" (Boltanski 1965, 194-196), this paper aims to show that photojournalism could be fruitfully interpreted through the theoretical framework of the "field of cultural production" (Bourdieu 1983; 1985; 1992; 1993). Such a conceptual application has both empirical and theoretically aims. In fact, even though Bourdieu himself employed photography as an ethnographic tool in his research (Bourdieu 2012; see also Robbins 2009), and he led a vast project that eventually theorized the social uses and symbolic legitimacy of photography as "a middle-brow art" (Bourdieu 1990), what is arguably his most influential analytical and conceptual framework - i.e. field theory - has (quite paradoxically) never seriously addressed photography. In its empirical focus on news photography, this paper also aims to offer a contribution to bridge that gap.

In fact, since the early 2000s - following also the central role acquired by Bourdieu's oeuvre within the cultural turn in the social sciences, which made him one of the most quoted authors in international sociological research (Santoro 2008; 2011) -, Bourdieu's field theory has been

\footnotetext{
${ }^{3}$ Throughout this paper, the translation of extracts from Boltanski (1965) is mine, as Boltanski's chapter on French photojournalism was excluded from the English edition of the book, Photography: A Middle-Brow Art, apparently and quite paradoxically because it was considered "not directly concerned with the theme of photographic practice" (Bourdieu 1990, xi).
} 
increasingly adopted within media sociology and political communication (Benson 1999; 2004; 2013; Champagne 2000; Couldry 2003; Benson and Neveu 2005) - after being long underrated ${ }^{4}$. In this context, rather than a "sociologist of media", Bourdieu comes to be increasingly considered as a "sociologist for media scholars" (Neveu 2007) - particularly those working on news production, where field theory has been articulated through the concept of the "journalistic field" (Bourdieu 2005; Benson and Neveu 2005; Benson 2006; Dickinson 2008).

As it is widely recognized, the "cultural field" indicates a relatively autonomous space of social and symbolic relations, generating a spectrum of reciprocally defined field positions. The social actors are dislocated in positions of core/periphery on the basis of two axes of distinction (i.e. symbolic/commercial value, consecrated/unconsecrated status) and of different distribution of various forms of capital. The actors thus conflictually elaborate definitions, norms, values, and "visions" concerning the practices of production, the producers and the products of the field. The concept of field thus describes a sphere of social action, or "microcosm", with its own external boundaries, internal logics and stakes, "rules of the game" and symbolic hierarchies, standards of practice and criteria of evaluation, and "field effects" - i.e. empirically verifiable changes in the structure of relations, positions and power.

What does it mean to consider professional photojournalism as a cultural field - and what could be gained by such a theoretical move? This process can be developed through four major steps.

1) Field position and boundaries. First of all, conceiving photojournalism as a field entails positioning it in the wider social space and in relation to other close fields - that is, to address the issue of its autonomy. As Fig. 1 shows, photojournalism can be visualized entirely within the wider fields of photography and journalism, and partly intersecting the field of fine art. On the one hand, notwithstanding its unquestionably increasing position over the last three decades, the field of photography still largely occupies a middle-brow position in the hierarchy of cultural legitimacy: it is a genre constantly in search of legitimation, as it is widely and easily accessible, both technically and economically, it does not necessarily require a specific cultural background in order to be practiced, and it has not yet fully and institutionally established a set of notions and standards to be self-reflexively, professionally and critically interpreted and evaluated - differently from more established high-brow forms of fine art (Bourdieu 1965). On the other hand, the field of journalism is structurally located in a lower and, most relevantly, increasingly market-driven position in modern Western societies (Bourdieu 1994; Benson 1999; Champagne 2000; Benson and Neveu 2005). Within the field of photography, professional photojournalism itself is structurally located in an intermediate position, in-the-middle between low-brow, often private/anonymous forms of photographic practice - e.g. family photography (Rose 2010) or even citizen (news) photography (Allan 2013; Andén-Papadopoulos and Pantti 2011) - and more authorial, consecrated and institutionalized ones - e.g. fine art photography (Fried 2008).

\footnotetext{
${ }^{4}$ In the social sciences, field theory has been extensively applied and critically refined in a variety of empirical contexts over the last three decades (e.g. Savage and Silva 2013; Hilgers and Mangez 2015). However, it has gradually entered the domain of the sociology of media and journalism only since the early 2000s, mainly because Bourdieu's previous work on television (Bourdieu 1996), originally conceived for a wide public, "was greeted by many Anglo-American media researchers with profound disappointment" (Hesmondhalgh 2006, 211; Marlière 1998), and it was even described as a form of "critique without reason" (Lemieux 2001). As Benson and Neveu $(2005,1)$ convincingly argued, most disappointment was expressed "without really understanding what the book, and more importantly, Bourdieu's larger theoretical project, has to offer".
} 


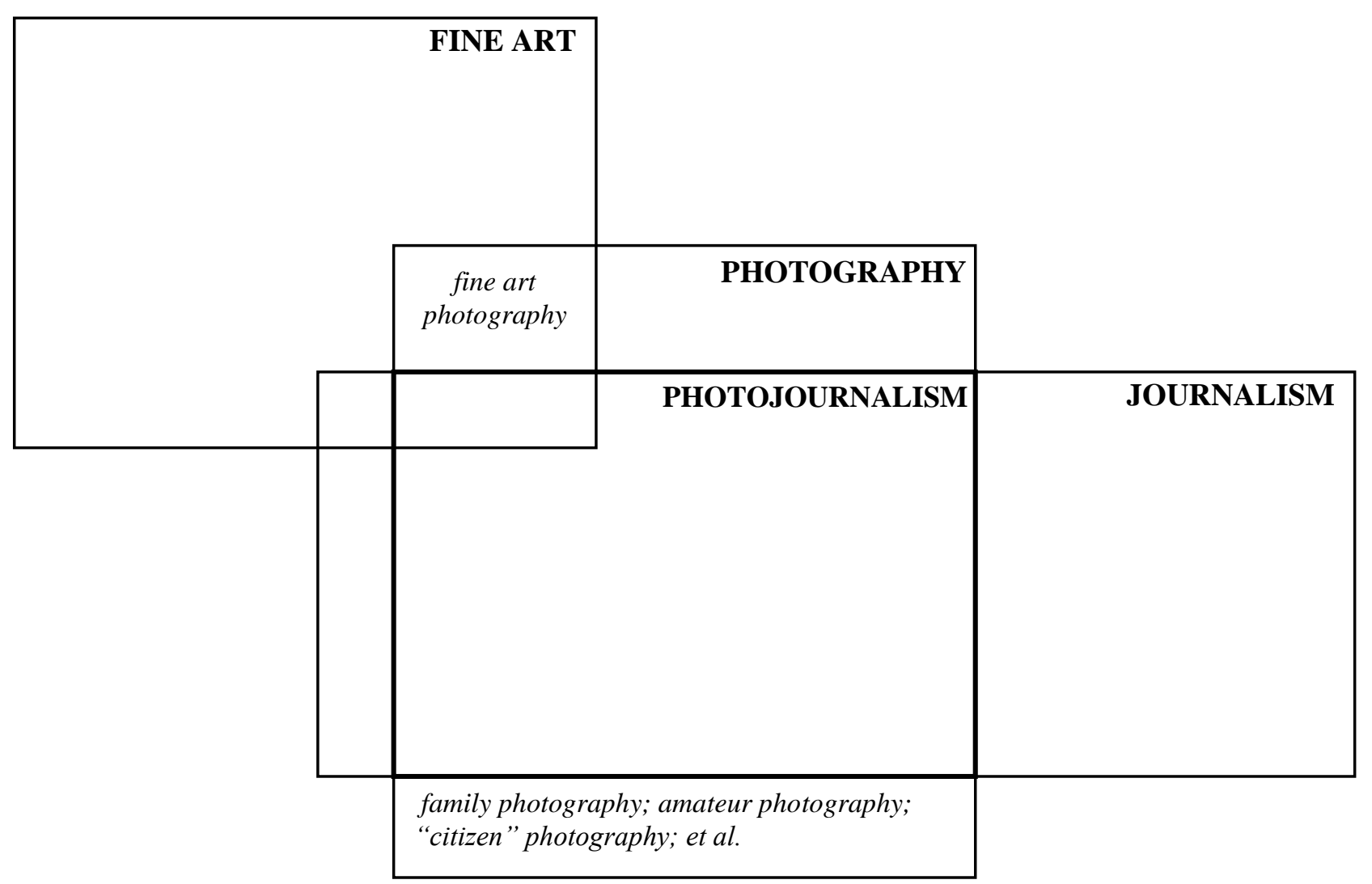

Fig. 1: The field of photojournalism, within the fields of photography and journalism, and intersecting the field of fine art.

2) National/global field. Considering photojournalism as a field also implies positioning it in relation to the increasingly global/transnational dynamics of news and cultural production - and spelling out reciprocally influencing local, national, and global dimensions. Over the last fifteen years, in fact, calls for analytical reorientation in the social sciences have increasingly urged to move beyond methodological nationalisms. Some Bourdieusian scholars have begun to focus on global/transnational flows, fruitfully conceiving wide political or academic structures in fieldtheoretical terms (e.g. Steinmetz 2008; Go 2008; Heilbron 2014). However, empirical investigation on news media and cultural production is still predominantly conducted within the borders of specific national contexts or, more rarely and effectively, comparatively (e.g. Thompson 2005; Sapiro 2010; Benson 2013) - even if attempts to build global/transnational mappings of different cultural fields (e.g. Casanova 2004; Kuipers 2011; Sapiro 2015) and to push sociological analysis "beyond structures and fluids" (Savage 2013) are gradually emerging. From a field-theory perspective, a wider analytical approach could "help sharpen the model and highlight how variable qualities of fields/institutions - in particular, the 'cultural inertia' of professional traditions and the organizational/spatial ecology of competition - account for characteristics of national and even emerging global forms of journalistic practice" (Benson 2006, 199-200). Even if "global journalism" is often employed simply as a terminological reference for comparative analysis of news media systems, new epistemological attempts to theorize the extent to which journalists explain news events in terms of their global interconnections and impacts have been recently developed among communication scholars (Löffelholz and Weaver 2008; Cottle 2009; Berglez 2013). In this context, it became clear that since flows of visual-cultural production are increasingly transnational, they should accordingly be investigated and explained beyond national prisms and within the complexly articulated global news ecology. Consequently, scholars increasingly argue for the "need to attend to both structures and agency and their mutual interpenetration and conditioning within the field of global journalism" in a way that must be "sensitized to the 
increasing complexities and contingencies, as well as shifting market determinations and strategic dynamics of power" (Cottle 2009, 42).

As fig. 2 shows, global professional photojournalism can be analytically conceived as an organic structure, including: multiple national fields as well as more restricted and mobile transnational elites of photojournalists; local/national as well as internationally circulating and influent newspapers and newsmagazines; national as well as global news and photo agencies - the latter with offices situated worldwide, often within "global cities" (Sassen 2002). Belonging to the transnational professional elite does not only mean being usually associated to a specific global agency's name, but also publishing on mainstream, widely diffused and influential Western newsmagazines, being constantly on the move, developing long-term and often high-risk photojournalistic projects on complex global crises and impending global issues (e.g. climate change, humanitarian crises, post-conflict reconstruction, etc.), which require a well-rooted illusio, deep entrepreneurial spirit, strong emotional commitment, and a well-articulated organizational network of material and symbolic resources. ${ }^{5}$

Within such a global ecology, any given national field is structurally located in a more or less peripheral position toward the central, transnational (supra-)field. For example, the French and the US national photojournalistic fields are arguably positioned in a more central position, as since the end of the Second World War they hat they have not only produced some of the most historically and professionally influential photojournalists (and photographs), but they have also gradually enjoyed a relatively high degree of institutionalization. The structural configuration of the global photojournalistic field could thus be metaphorically described as a "double track", whereby, on the one hand, most photojournalists keep struggling to reach acceptable working conditions and both symbolic and commercial recognition at the national/local level, while, on the other hand, a restricted elite of transnational photojournalists are increasingly moving (up) on the "fast lane", even occupying top positions on the global hierarchy of symbolic power of photojournalism.

\footnotetext{
5 A major distinction between transnational, national and local photojournalists deals with their degree of mobility, and the possessed volume of "network capital". The notion of "network capital" was developed by Elliott and Urry (2010), within a wider "paradigm of mobilities", as a theoretical attempt to re-articulate Bourdieu's notion of social capital within the increasingly digital-technological context of "networked individualism" in the late-modern society. Network capital identifies "the capacity to engender and sustain social relations with those people who are not necessarily proximate, which generates emotional, financial, and practical benefit ... [and] often entails various objects and technologies or the means of networking" (Elliott and Urry 2010, 59). In the field of global photojournalism, network capital refers to the capacity to technologically develop and sustain social and professional relationships among different actors variously dislocated worldwide, such as the photojournalists covering a given area or event, the photoeditors within the newsrooms, and other professional figures - e.g. experts in post-production, who technologically enhance the photographs before publication, on the basis of their volumes of specific "digital cultural capital" (Solaroli 2015).
} 


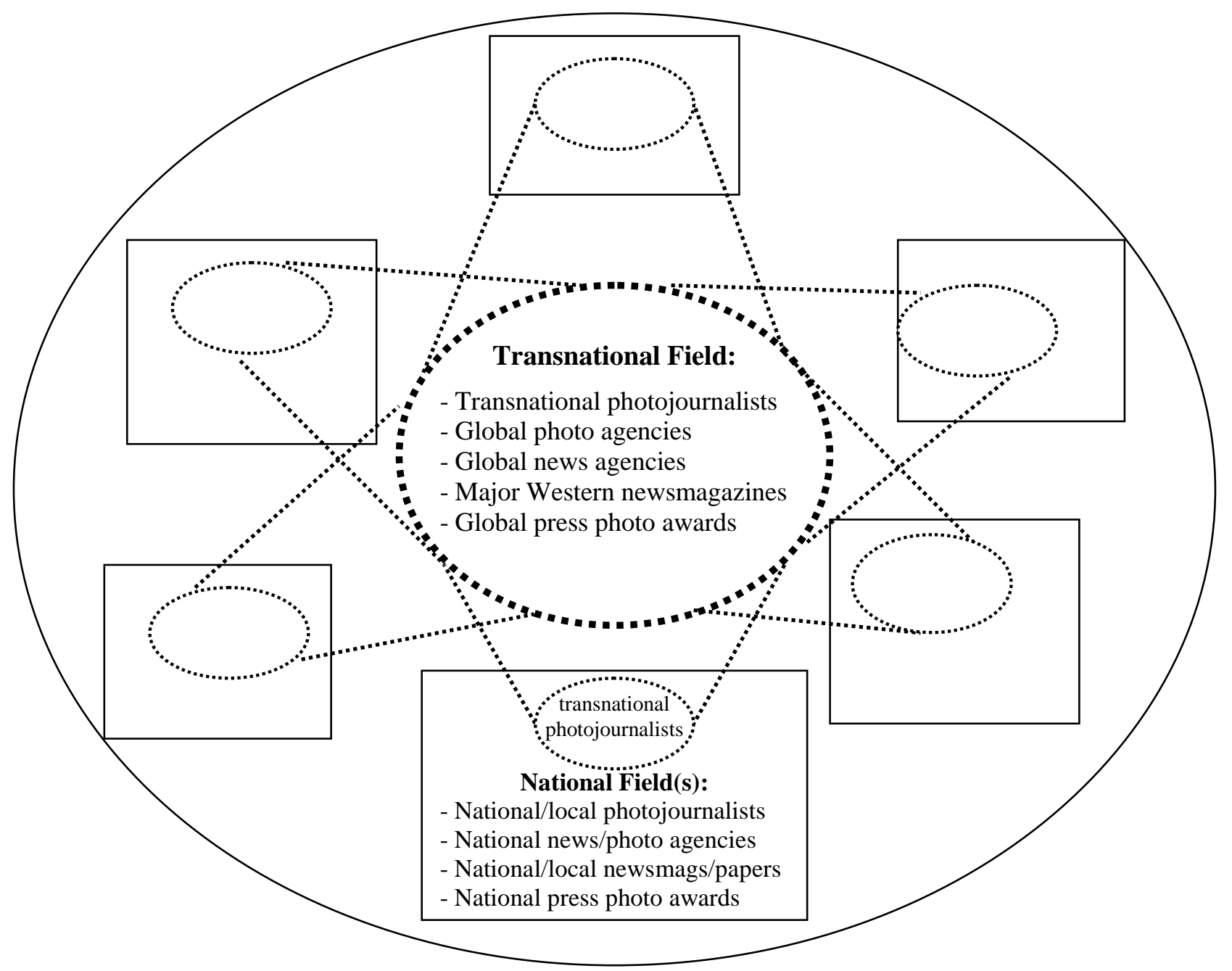

Fig. 2: The national/global levels of the global photojournalistic field: (more or less peripheral) national photojournalistic fields, transnational photojournalists, and central-transnational (supra-)field.

3) Field's internal structure, capitals and positions. Considering photojournalism as a cultural field implies identifying the internal principles of differentiation and the wider logics of the field. Cultural fields are usually structured according to two opposing principles of differentiation, which shape two main axes of distinction: 1) the opposition between the autonomous pole of the subfield of restricted production (where the ruling principle is "art for art's sake", and the products are conceived for a relatively restricted market of producers and consumers with high volumes of specific cultural capital, who are able to recognize, decipher and appreciate "pure" forms of cultural production) and the heteronomous pole of the subfield of large-scale production (where the aim is reaching the potentially largest market, the level of authorial control of the producers can be lower, and the products are supposed to be conceived in order to be sold and quickly distributed rather to express particular symbolic meanings, therefore independently from the volumes of cultural capital of the consumers); 2) within the subfield of restricted production, the opposition between the consecrated avant-garde and the unconsecrated avant-garde, the established producers and the newcomers, i.e. between generations. New entrants can create and/or occupy new positions in the field and affirm their existence by searching for the consecration by already established actors or, alternatively, by questioning their older, legitimate and dominant models of cultural production (Bourdieu 1983; 1985; 1992; 1993).

In the photojournalistic field the heteronomous/autonomous distinction becomes manifest in the differences between, on the one hand, photojournalists working for global stock photo agencies or more frequently - within the wire-photo departments of market-driven and globally distributed 
news agencies (e.g. Reuters, AP, AFP), which tend to produce aesthetically standardized and "highly situated - geographically, institutionally, and culturally - visual products that have the potential to circulate globally as factual, seemingly transparent, representations of the world as it is" (Gürsel 2012, 84); and, on the other hand, photojournalists working within a more restricted and less market-dependent circuit, such as for major cooperatives of photographers and autonomous photo agencies (e.g. Magnum, VII, Noor). In the first case, the photojournalist has very scarce control over the distribution of his/her photographs to a variety of newsrooms throughout the world - which usually access the same news agency archives, and can thus even risk to publish the same pictures. In the second case, the photojournalist can exercise higher control over the production and distribution of the photographs, usually realized on the basis of pre-negotiated assignments with the commissioners - e.g. international newsmagazines. The photographs produced in this subfield often circulate also through photo-books and photo exhibitions - in galleries, photo/journalistic festivals, and even museums.

Instead, the consecrated/unconsecrated distinction can be traced by defining the fieldspecific form of symbolic capital. In every field, in fact, social actors are structurally positioned and differentiated according to the volumes of capital they possess - and they need, in order to play the game. The global photojournalistic field's "specific symbolic capital" (CSs) is symbolic capital conferred by the accumulation of field-specific forms of prestige and consecration, such as publishing in major newsmagazines, exhibiting within major festivals, entering prestigious photo agencies, and winning photographic and journalistic prizes and awards - i.e. institutional vehicles for the performance of value within the "economy of prestige" (English 2005). A paradigmatic example of a professional photojournalistic group that has acquired huge symbolic capital is Magnum Photos - one of the oldest and most consecrated photo agencies, owned by its photographers-members. It clearly expresses that peculiar symbolic process defined as "corporative effect", that is, "an instrument for accumulating and concentrating symbolic capital (with the adoption of a name, the drawing up of manifestos and programmes and the setting up of aggregation rites, such as regular meetings ${ }^{6} \ldots$ from which the most famous ... groups have drawn immense symbolic profits" (Bourdieu 1992, 267-268). Emerging photographers (with low volumes of specific symbolic capital) struggle to enter its myth, to benefit from its prestige within the symbolic economy of global photojournalism - as well as to acquire higher degree of visibility in the wider visual economy. ${ }^{7}$ In order to better understand the accumulation of such a degree of visibility, a second form of capital can help, i.e. the "capital of visibility". The concept was developed by Heinich (2012), drawing also on Bourdieu (1975), in an investigation of the constitutive role of visibility in social life, and the power of mediatized celebrity in the "field of visibility" (Brighenti 2010). Capital of visibility identifies the capacity to be seen and recognized by others, an "objective quality of people, very unequally distributed" (Heinich 2012, 493) but "measurable, accumulative, transmissible, interest-bearing, convertible" (Heinich 2012, 51) therefore sociologically useful. For professional photojournalists, capital of visibility refers to the capacity of acquiring public visibility not only within but also, especially, beyond the journalistic field, in the field of photography, in other fields (e.g. fine art), and in the wider visual public culture.

\footnotetext{
${ }^{6}$ Magnum (and other agencies') photographers-members annually meet in a different global city, for a ritual of aggregation that can enforce face-to-face social interactions, emotional investment and group loyalty among professionals who are usually distant and constantly on the move (on Magnum meetings, see Miller 1997).

${ }^{7}$ Such a structural configuration of the objective relations that constitute the professional field of photojournalism has long been in place. Analysing the practices of production of the photojournalists working for the French newsmagazine "Paris-Match", Boltanski (1965, 192) observed how they opposed themselves, "with a mixture of respect, envy and sometimes contempt, to the "pure" [photographers], for example Magnum photographers, those who are not subject to any newspaper in particular, and can thus realize at peace with themselves what represents, in their eyes, the legitimate photography, the only one truly authentic, the one they would like to practice if they were not slaves of the demands of their newsmagazine and its public: the great reportage."
} 


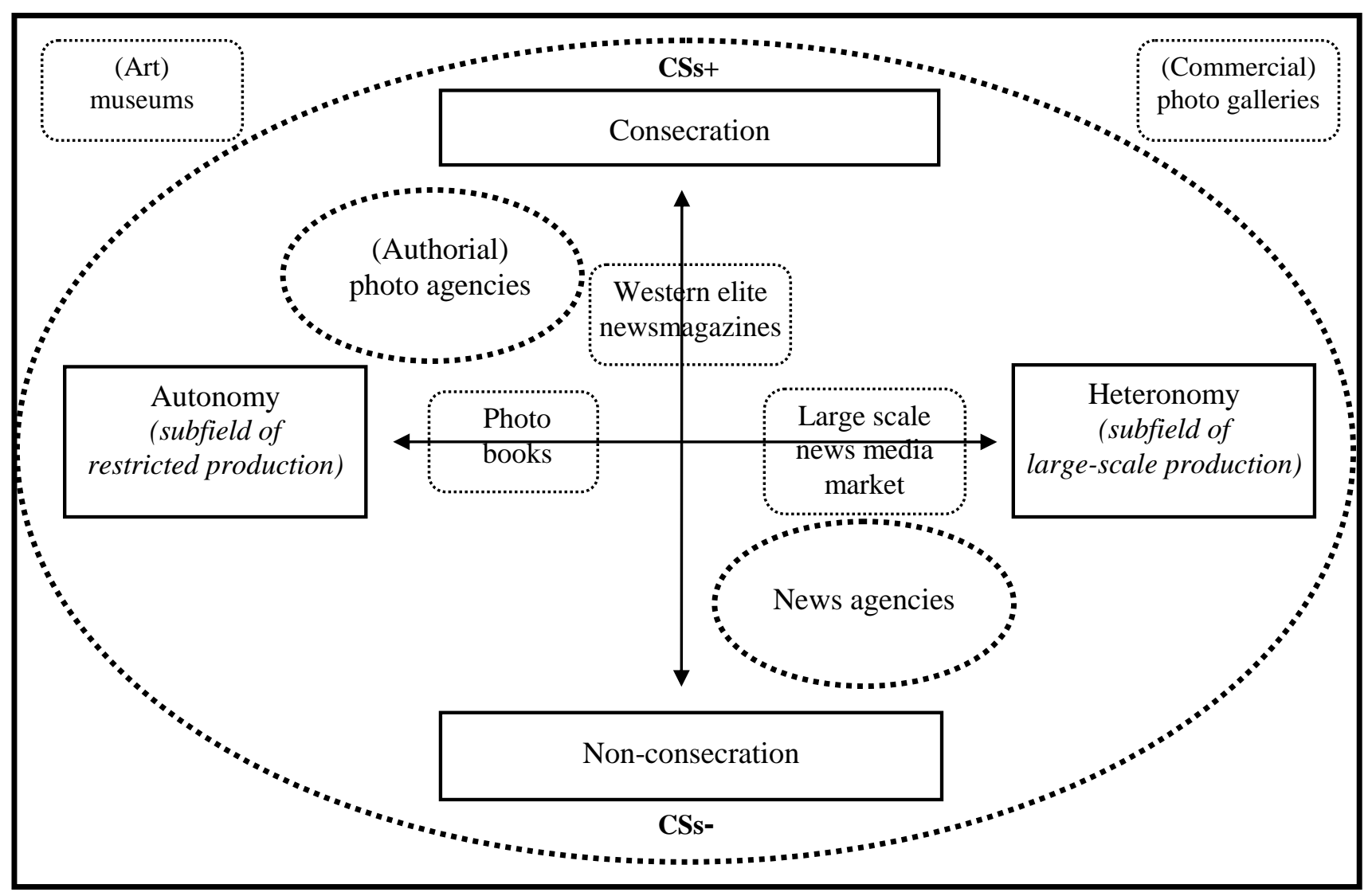

Fig. 3: The dominant axes of distinction in the global field of professional photojournalism (with the main publication contexts).

4) Field effects. Lastly, conceiving photojournalism as a cultural field implies identifying the major field effects, e.g. by analysing the impact of new entrants and their the strategies of positiontaking onto the overall structure of the field, the distribution of different forms of capital, and the relations between the two internal subfields - but also between fields. In fact, besides the internal field-analysis - the analysis of the structure of objective relations among positions occupied by photojournalists competing for symbolic power - it is necessary to develop a wider analysis of the position of photojournalism in the hierarchy of cultural legitimacy, and its transformations over time, by focusing on the relations and boundaries between the photojournalistic field and other fields, e.g. journalism and fine art.

Fig. 4 shows the overall structure of the global photojournalistic field, comprising the four analytical dimensions identified so far. As a conceptual framework, the "global field" can help to relationally position different social actors (with their different volumes of capitals, career strategies, professional practices and cultural products) in the social space at different historical times, and to explain structural changes by unveiling the social conditions and symbolic struggles that enable cultural innovation and professional consecration - as the next paragraph will show. 


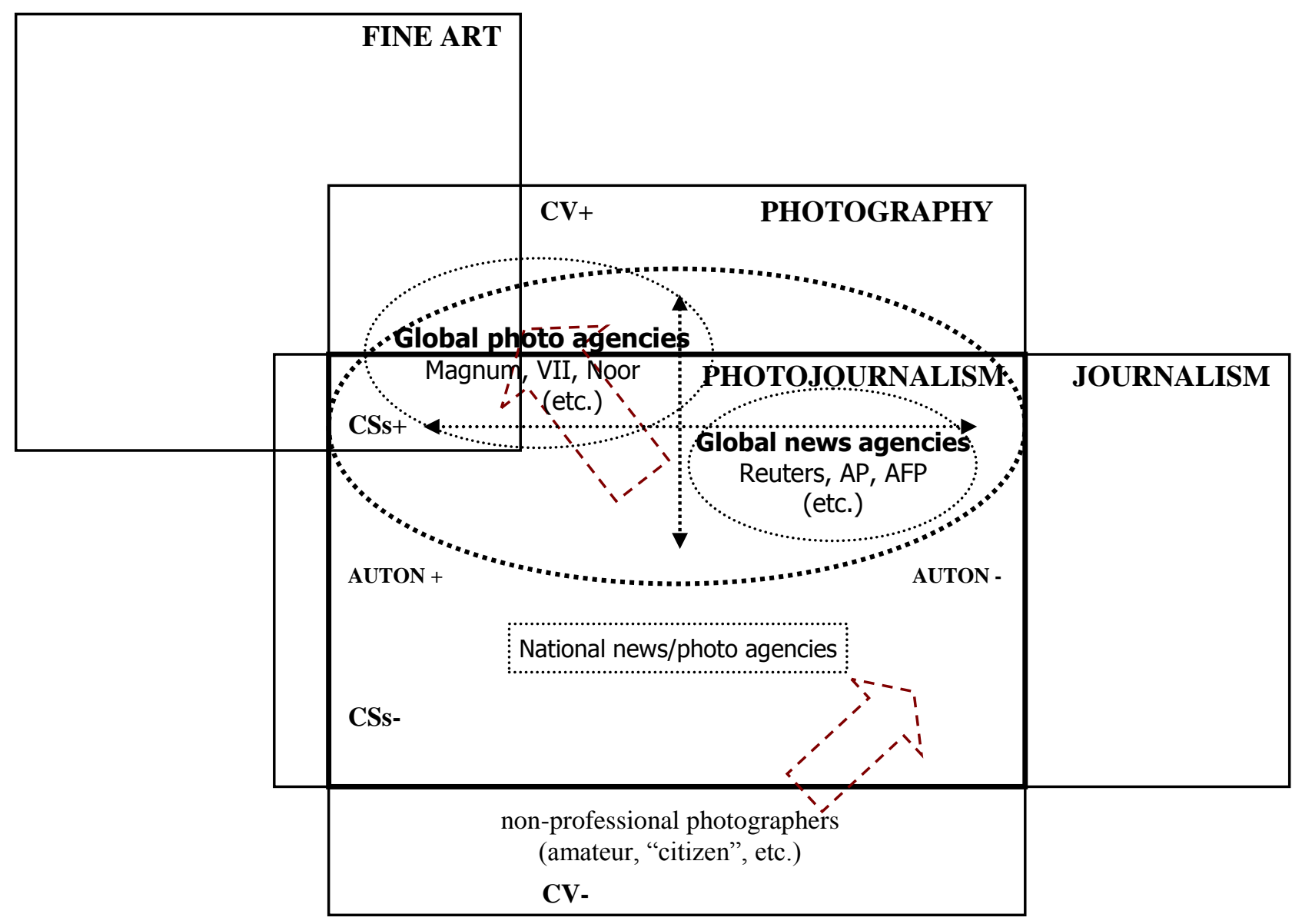

Fig. 4: The structure of the global photojournalistic field.

Legend:

$\begin{array}{ll}\square & \begin{array}{l}\text { National photojournalistic field(s) (peripheral) } \\ \text { Transnational photojournalistic field (central) }\end{array} \\ \text { AUTON+ } & \text { High degree of autonomy (autonomous pole) } \\ \text { AUTON- } & \text { Low degree of autonomy (heteronomous pole) } \\ \text { CSs+ } & \text { High volume of specific Symbolic Capital (consecration) } \\ \text { CSs- } & \text { Low volume of specific Symbolic Capital (non-consecration) } \\ \text { CV+ } & \text { High volume of Capital of Visibility } \\ \text { CV- } & \text { Low volume of Capital of Visibility } \\ --:- & \text { Field effect }\end{array}$

\section{Practices and forms of consecration: Photojournalistic styles and the search for authorship}

On the basis of the conceptual framework of the global photojournalistic field, it is now possible to empirically focus on the symbolic struggles for distinction and power that have been taking place over the last two decades. In particular, this section provides a comparative analysis of a few specific news photographs produced by different actors differently located within the field. On the basis of the archive research, the photographs have been chosen as paradigmatic examples of much wider bodies of work, as they are exemplary of the process of stylistic innovation (vis-à-vis traditional mainstream visual-representational forms of photojournalism) and professional positiontaking in relation to the wider symbolic struggle for consecration. Their textual-compositional analysis is enriched by the interviews conducted with major photojournalists and photo-editors, in order to trace the photographs' aesthetic forms back to the practices of production and the strategies of distinction among different photojournalists, photo agencies, and major newsmagazines in the global field. 
Fig. 5 and Fig. 6 visually condensate a deeply structuring symbolic distinction between established photojournalists working for market-oriented news agencies or wire-photo agencies (e.g. Corbis) and established photojournalists working for more autonomous and authorial photo agencies (e.g. Magnum) (see Fig. 4).

Peter Turnley (b. 1955 in Fort Wayne, US) (Fig. 5) is an internationally renowned photographer who was on contract for Newsweek from 1986 to 2001. In 2001, Sarah Harbutt was appointed Director of Photography at Newsweek. As the daughter of famous Magnum photographer (and President) Charles Harbutt - thus benefiting from her family's social, cultural and symbolic capital - she set out to develop a project of renewal of the newsmagazine's photojournalistic approach. In the same year in which Turnley's collaboration with Newsweek ended, Harbutt offered a contract position to Magnum photographer Paolo Pellegrin (b. 1964 in Rome) (Fig. 6). Pellegrin has then been a contract photographer for Newsweek for a decade, and today he is one of the most internationally prominent photojournalists.

Both Turnley and Pellegrin were on the road to Baghdad in early April 2003, and both of them photographed a member of a pro-Saddam militia unit taken for burial after being killed while fighting British soldiers near the city of Basra. In the first case (Fig. 5), Turnley's photograph focuses on the dead body, and the recognizably expressive faces of the subjects around him. Classically composed according to a formal diagonal created by the positioning of the different figures, running from the feet of the dead (bottom-left) to the shadows of the two men (top-right), the (colour) photograph is rich in details, and it conveys visually clear and journalistically relevant pieces of information. In the second case (Fig. 6), instead, Pellegrin's black-and-white photograph does not apparently hold the same traditionally defined journalistic value, as a considerable section of the frame is occupied by the back of an unidentifiable subject wearing a black burqa, while other subjects are carrying an apparently dead body at great distance from the photographer, and their face and expressions are not visible. Such representational features seem to reveal the practical attempt of the photojournalist, on the one side, to make the (western) viewers possibly share the point of view and the emotions of the Iraqi woman, to empathically identify with her state of mind (and arguably her loss), but also, on the other side, and at the very same time, to make the photographer himself add his signature to the frame. In order to take such a photograph, in fact, Pellegrin carefully waited for the right moment - when the men were on their way, and the woman was left close to him - then he positioned himself behind the woman, and finally he took the photograph, by slightly tilting the camera: in short, he creatively took a risk in order to get a distinctive result. Had the aim been to provide the standard photojournalistic picture, such a risk would have been dangerously unnecessary. Instead it turned out to be instrumental in order to expressively add his own authorial voice to the frame.

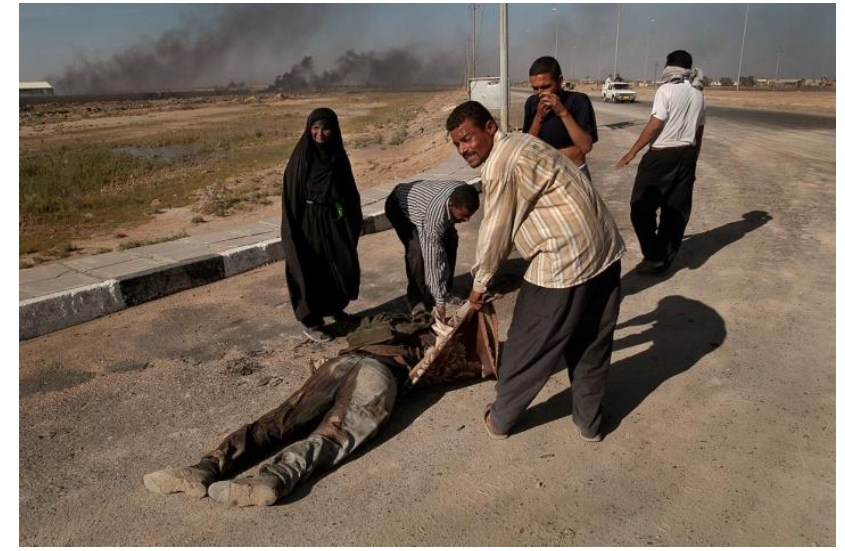

Fig. 5. Peter Turnley (orbis), Basra, Iraq, 04.03.2003.

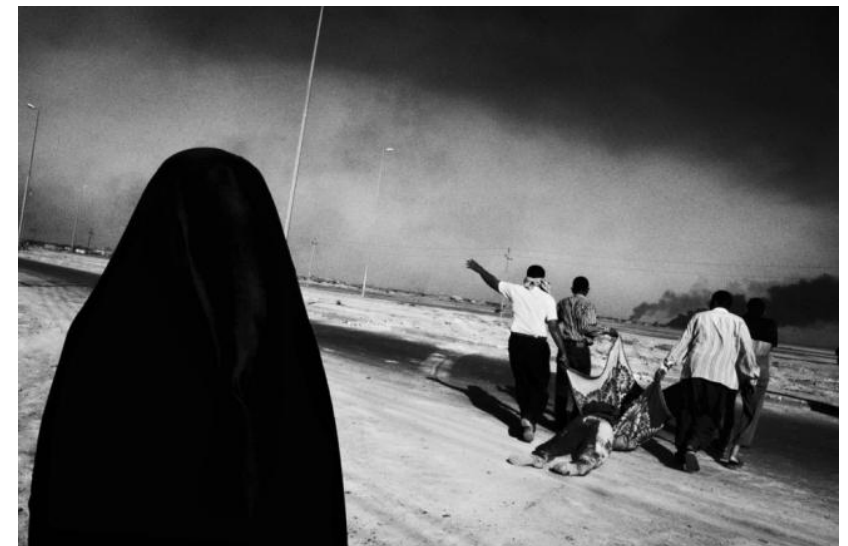

Fig. 6. Paolo Pellegrin (Magnum), Basra, Iraq, 04.03.2003.

Fig. 7 and Fig. 8 show two photographs from two different reportages on the Darfur crisis published in the same period (October 2004) on Time and the New York Times magazine. The first 
reportage (Fig. 7) was produced by James Nachtwey (b. 1948 in Syracuse, US) - a highly established and prized photojournalist, Magnum member for fifteen years, then co-founder of the global photo agency VII. The second reportage (Fig. 8) was produced by Pellegrin. If we compare the two photographs, then it becomes clear how Pellegrin's approach aesthetically resulted in a very blurred image, lacking immediate reference. Such a photograph (taken in a refugee camp in Darfur) quite manifestly breaks with the historically established informal repertoire of photojournalistic conventions, such as the close-ups and frontal shoots of explicitly recognizable physical actions, expressive faces, and detailed contexts - as they are shown in Nachtwey's photograph. On the contrary, Pellegrin's photo does not indeed appear easily recognizable at first sight, especially without a caption. As such, it seems to confirm Bourdieu's suggestion that photography could provide "the means of dissolving the solid and compact reality of everyday perception into an infinity of fleeting profiles like dream images" (Bourdieu 1990, 76). Slightly out of focus and much darker than Nachtwey's, Pellegrin's photograph can be argued to look evocatively richer, yet informatively poorer.

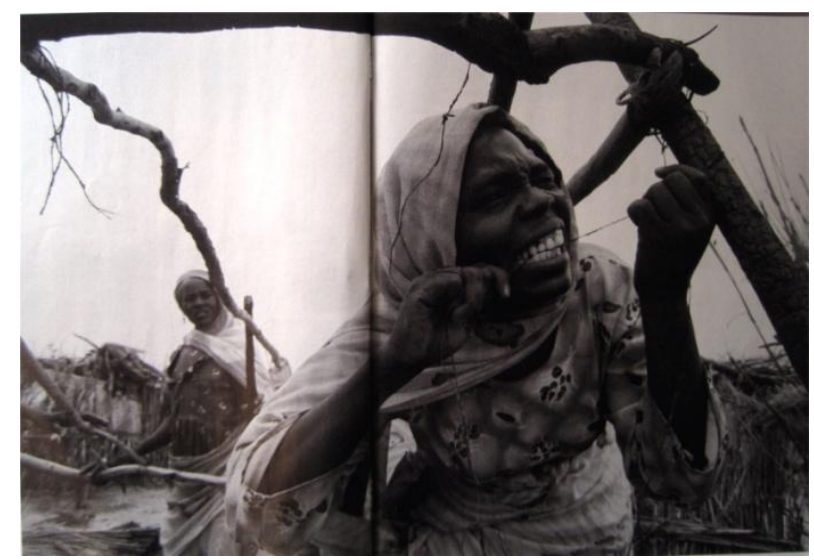

Fig. 7. "The Tragedy of Sudan",

TIME, Oct. 4, 2004, pp. 48-49.

Photo by James Nachtwey ( $\underline{\mathrm{VII}})$.

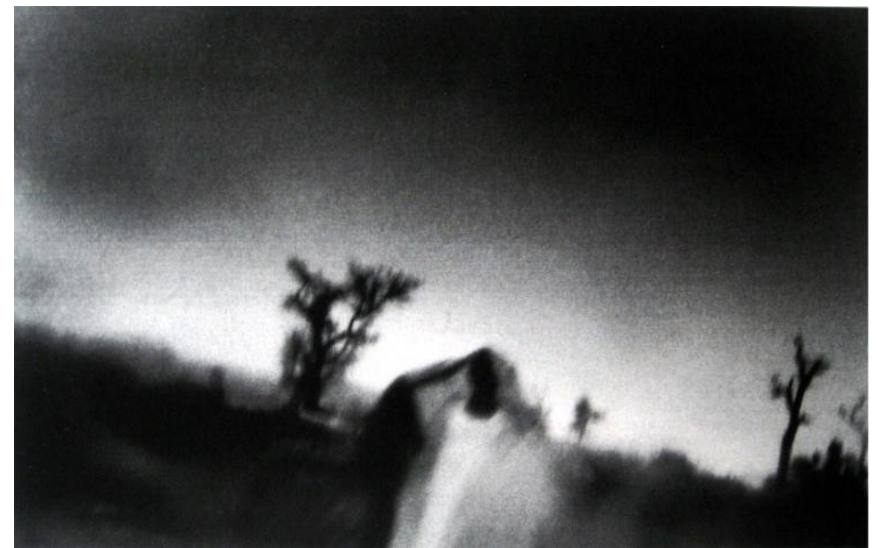

Fig. 8. "How Did Darfur Happen?",

New York Times Magazine, Oct. 17, 2004, p. 6. Photo by Paolo Pellegrin (Magnum).

Kathy Ryan is Director of Photography at the New York Times Magazine, which is largely considered as one of the most authoritative and influential newsmagazines in the global photojournalistic field. In her words, Pellegrin comes to be defined as "a very poetic photojournalist" who has "left behind the tools of detached documentarian":

A big part of the job you do as an editor is to figure out how you tell the story in a new way, how you find a new angle, how you go against the expectations of the readers ... That translates photographically in my wanting to commission photographers who bring a different kind of point of view, even a literary point of view, Paolo Pellegrin being the best example. He's a great reporter, that would be meaningful information, as well as his way of looking at something and interpreting it, adding to what our readers might already know about the story ... This kind of rich chiaroscuro, this kind of very artful... soulful, a more existential quality... I love that stuff ... I like that kind of risk taking, the picture is black ... so out of focus, so mysterious, it gives the anxiety. What Paolo does often is the pictures can provoke anxiety in the viewers, and I love that ... they can look at this and feel a little bit of their stomach turning, and a sense of the danger, the sadness. ${ }^{8}$

James Wellford has been a senior international photo-editor at Newsweek for twelve years (20002012). In his words, Pellegrin's approach comes to be similarly defined "very effective" to convey emotions, feelings, "a sense of anxiety":

\footnotetext{
${ }^{8}$ Kathy Ryan, interview with the author, New York, January 2014.
} 
If you think at a world which is completely devastated, if you talk about an infrastructure that had inherently imploded... How do you render that? How do you show it? I often think that the ability to render more abstractedly places and feelings in Paolo [Pellegrin]'s hands can be very, very effective ... it could be extremely effective if you talk about a world in turmoil. Where he is able to convey an emotion, a feeling... a sense of anxiety. What you can have there is not so much about closure, but an opening... to walk in... something to think about ... very much like an idea, a concept. ${ }^{9}$

On his side, referring to his photographs from Darfur, Pellegrin explained his professional approach to photojournalism as a struggle to look for what he defines as an "open" photojournalistic language:

I'm moving on a very dangerous edge. I'm conscious of it ... I look for "open", "unfinished" pictures, which ask the observers to "enter" them, to be stimulated by them, to discuss. If an image is too "close", too static and defined, then it can't live its own life and become, through my camera, a sign of the subject, for the world ... Photography is a complex language and through my work, a photograph taken in a refugee camp can go beyond that specific refugee camp. When I eventually succeed, tents and refugees become a reflection on what it means to escape, to leave your own house, to lose your roots, to become a refugee. There, or everywhere else. ${ }^{10}$

Francesco Zizola (b. 1962 in Rome), is an internationally renowned photojournalist who has focused on a variety of major social issues and their effects on human population - from poverty, civil wars and humanitarian crises in the global south, to pollution, corruption and politics in the rich north. After a brief experience within Magnum, he co-founded the global photo agency Noor in 2007. Like Nachtwey's, Zizola' production can be situated within a cultural tradition of classic humanistic, mostly black-and-white photojournalism, which has constituted the dominant representational paradigm of Western professional photojournalism since the end of the Second World War (Hamilton 1997; Cookman 2009), producing formally composed images whose content often reveals the engaged photojournalist's illusio - i.e. the belief in the moral-historic role and potential socio-political effect of news photography. Implicitly - and critically - addressing Pellegrin's work, Zizola argued for a clear-cut distinction between "photography" and "photojournalism":

Photography can be fantastic, imagined, retouched, flashed, artistic, poetic... and that's the kind of photography increasingly used by newsmagazines which should be journalistic ... So we have to front huge paradoxes: mainstream magazines such as The New York Times Magazine and Newsweek decided to illustrate the conflict in Iraq with blurred photographs, slightly out of focus, with a lot of clouds and silhouettes. I would define them conceptual photographs. In these cases the photographer does not really want to show too much what is around... by removing reality, instead of adding it! Some of these photographers claim to be authors of a new way of interpreting reality ... But where are the founding values of our profession, such as the use of different frames and close-ups, the depth of the field of vision, the effort to show the context? How can we tell what is going on in the world exclusively through such an aesthetic conceptualization? Evoking, rather than showing? In my opinion, rather than news, all this has to do with a stylistic research to produce photographs that can be easily exhibited within art galleries. ${ }^{11}$

As the last two excerpts significantly confirm, "the meaning conferred on photography is always positional and oppositional" (Bourdieu 1990, 106): what is at stake is the very power to define professional photojournalism, its legitimate practices and representational forms, and its social and

\footnotetext{
${ }^{9}$ James Wellford, interview with the author, New York, January 2014.

${ }^{10}$ Paolo Pellegrin, interview with the author, London, September.

${ }^{11}$ Francesco Zizola, interview with the author, Rome, January 2010.
} 
symbolic boundaries (e.g. between "news" and "art" photography). From this viewpoint, Zizola's and Nachtwey's photographs represent paradigmatic examples of a classically conceived approach to photojournalism, where the professional mission of bearing witness and the news value of the realism of the representation come to be aesthetically resolved in a mostly black-and-white and formally rigorous photographic balance between close-ups and depths of field. Therefore, from a field-theoretical perspective, Zizola's polemical tones represent a possibly boundary-reinforcing element of one social actor's own position vis-à-vis the process of distinctive position-taking by other, rapidly emerging newcomers who are struggling for consecration and power by putting the orthodoxy into question.

In fact, Pellegrin's photojournalistic style falls paradigmatically within a wider intergenerational struggle for stylistic innovation and authorial consecration within the global photojournalistic field. On the basis of the archive research and the interviews, it could be argued that such a symbolic struggle was fragmentally and individually ongoing since the 1990s, but it took a public collective shape in 2004, when four emerging Magnum Photographers (Paolo Pellegrin, Alex Majoli, Ilkka Uimonen and Thomas Dworzak, who were later joined by Antoine D'Agata and Christopher Anderson), decided to gather their efforts and to organise an exhibition that, for the first time, reflected this new photojournalistic vision and this new social group of assertively up-and-coming photojournalists. Interestingly, the photojournalists in this group were almost all Europeans: two Italian, one German, one Finnish, one French (plus one American) - in other words, they came mostly from historically peripheral and scarcely institutionalized national photojournalistic fields (the US and French fields being the most central since the mid-twentieth century). The exhibit was shown in Manhattan in Spring 2004, and it was entitled "Off Broadway", from the New York City area where alternative theatre was established, thus highlighting their manifested distinctive intentions. The photos belonged to reportages from Kosovo, Afghanistan, Iraq, Palestine, Ethiopia and Chechnya (Fig. 9). Most relevantly, they were all jumbled together, and it was impossible to clearly identify the single authors.

According to Alex Majoli (b. 1971 in Ravenna, Italy), an internationally renowned photojournalist who belongs to the recently consecrated transnational elite - and, significantly, who was elected President of the prestigious global agency Magnum Photos in 2011, at forty years old -, the exhibition was "very important" both "within Magnum" and for the whole photojournalistic field:

\footnotetext{
I believe that Off Broadway has been very important for photojournalism ... People couldn't understand why we didn't "sign" the photos... The exhibition's impact was that apparently there was no authorship, there wasn't the name of the photographer who had shot the picture, all the photographs were mixed together, they had been edited all together... It was incredibly successful... At the opening the street was full of visitors... And it surely mattered a lot within Magnum... I clearly remember the day of the opening, we had the keys of the location, and we went there earlier on... There were myself, Ilkka [Uimonen], Thomas [Dworzak], together with Luc [Delahaye]... just us, alone. It's been very important ... We wanted to re-innovate the tradition, debunking the myth of the "Magnum photograph" - the Leica-made black-and-white "decisive moment" photograph. ${ }^{12}$
}

The "Off Broadway" exhibition played a relevant role within the inter-generational struggle for consecration in the field because, more than focusing on the single photojournalists, it strongly contributed to socially construct, officially define, and publicly convey a sense of rapidly emerging collective group, bound together by similarly innovative photojournalistic styles and shared authorial ambitions - as well as by a relevant involvement in terms of "emotional energy" (Collins 1998). Between 2004 and 2006, the exhibition travelled internationally. Relevantly, in Italy it was shown within Milan's Pavilion of Contemporary Art, and in the press reviews it was subtitled "Six photographers in search of an author", explicitly evoking Italian writer and Nobel prize laureate

\footnotetext{
${ }^{12}$ Alex Majoli, interview with the author, New York, January 2014.
} 
Luigi Pirandello's most famous literary work, "Six characters in search of an author" - thus suggesting a relationship between such a new group of photojournalistic authors and the high-brow field of literature.

On this basis, it becomes clear that the process of consecration of the group of photojournalists who have acquired impressive symbolic power and journalistic visibility over the last decade in the global professional field presupposes the articulation of a recognizably distinctive aesthetics with deeply subjective implication - i.e. the construction of their status as "photojournalistic authors" (Morel 2006). In the search for a distinctive position in the field, these photojournalists strived to defy traditional photojournalistic styles and techniques (e.g. the frontal and detailed shoot) in favour of a less shockingly direct and more symbolically and subjectively articulated form of authorial production. Rather than exclusively providing the reader with traditionally conceived visual news, their photojournalistic styles - the stress on the obscured evidence of the facts, the enigmatic presence of shadows and silhouettes, and the often blurred and grainy texture of the photographs - aim at conducting the spectator into an emotional sphere of imaginative speculation. As a whole, their styles come to define a "dark fuzzy" aesthetics, full of darkness and opaqueness, and characterized by the choice of tilting the camera (Fig. 6;8), the use of portable flash (Fig. 10), and the adoption of an often decentred composition, slightly out of focus (Fig. 8; 9) - plus, often, a considerable amount of digital post-production, to enhance the aesthetic surface of the photograph (Fig. 8; 10). ${ }^{13}$

As Bourdieu $(1990,79)$ noted, "a different aesthetic might intentionally aim for the blurred or unfocused pictures which the popular aesthetic rejects as clumsy or unsuccessful". That comes as no surprise: in the absence of largely shared aesthetic theories and deeply institutionalized cultural authorities that could objectively define a hierarchy of forms, practices, and values, any successful strategy of position-taking in the field must be at least initially characterized by the refusal of the ordinary and the questioning of the orthodoxy. At the same time, as Boltanski (1965, 193-194) already observed, in certain cases within the field of photojournalism the "soft focus" can (paradoxically) constitute "the best guarantee of the pureness of the photographer's intentions ... the flaws of the framing, the thickness of the grain, recall the moment in which the picture was taken and they are like the trace of the encountered difficulties... The scarce readability ... guarantees the authenticity of what is being seen" (Fig. 9).

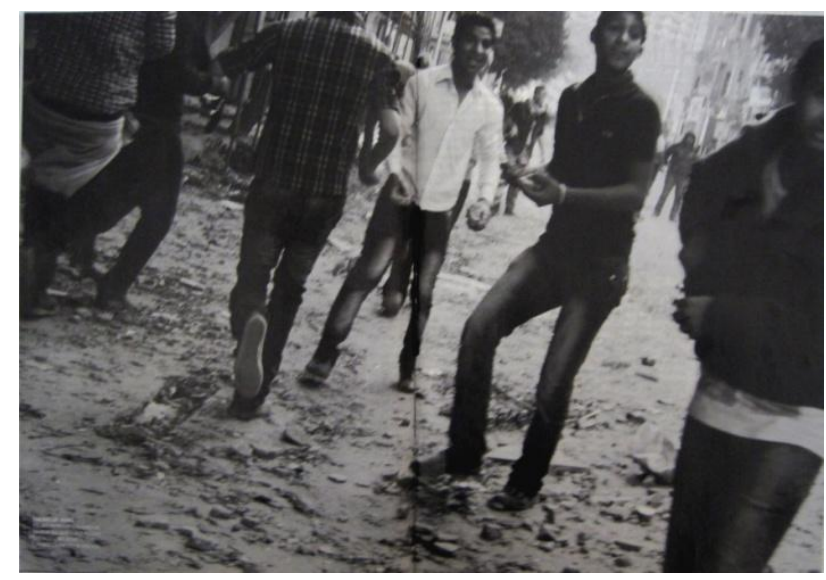

Fig. 9. "Demise of the dictators",

Newsweek, Feb. 14, 2011, pp. 22-23.

Photos by Alex Majoli and Paolo Pellegrin (Magnum).

However, in order to be eventually consecrated, every practice of stylistic innovation and professional distinction must be accepted and widely diffused. Within such inter-generational struggles, the primary vehicles of circulation of these kinds of photographs, of realization of the

\footnotetext{
${ }^{13}$ On digital post-production and professional consecration in photojournalism, see Solaroli 2015.
} 
emerging photojournalists' strategy, and of accumulation of symbolic capital and capital of visibility have been major Western newsmagazines. Bourdieu $(2000 ; 1994)$ drew attention to how competitive relationships between different newsmagazines can shape each one's coverage - even, it should be added, visually. In this context, the first half of the 2000s registered a deeply competitive struggle among different US elite newsmagazines, which had to front a rapidly technologically, politically, economically - changing and increasingly complex (news) world. In a renewal of their own photo departments, some of them, particularly "The New York Times Magazine" and "Newsweek", aggressively employed younger and innovative photojournalists to produce distinctive photographic essays which could stand out in a saturated, digital visual media environment characterized by an increasingly fragmented, dispersive and superficial attention threshold.

Recalling the role of Newsweek in the shifting photojournalistic field in the early 2000s, senior international photo-editor James Wellford explained:

At that time, photography moved to make it a much more significant contribution to what the magazine was all about ... There was a moment of collective belief in that, yea, let us [at the Photo department] re-contribute to the magazine... in the renewing we were trying to give some sort of new energy to the masters [master photographers] ... it was a very heavy, very creative and emotional time ... Each of the masters who were in a place like Newsweek, they represented a shifting approach to photography... We were trying to get people who were not driven just by their ability with the camera, but their ability on how to approach and navigate stories. Each of them had a nuanced voice, a different way of approaching visually ... So there was a radical enough transition at that time, visually, creatively.

In his words, the charisma of the rapidly emerging photojournalistic authors employed at Newsweek derived by their professional ability to produce more conceptually rich and emotionally affective news photographs, which aimed to visually convey the spectator not just the "objective" information of what was going on in a particular context - i.e. a historically constructed value of the photojournalistic profession (e.g. Schwartz 1992; Zelizer 1995) - but also the "subjective" sensation of what it felt like to be there - often in the midst of intense chaos, danger, tension, drama, confusion, apparent irrationality, and collective fear, like during the day of the terroristic attack in Paris in November 2015 (Fig. 10):

A lot of these stories we were going after didn't give themselves very freely... the IsraeliPalestinian issues, the civil wars... not easy to articulate, and depended to a large extent on the instincts, on the approach, on the sensibility of people like Luc Delahaye, Alex Majoli and Paolo Pellegrin... These people do want - to the extent that they are responsible of the objective sense of where they are - they do want that personal sense, too. ${ }^{14}$

\footnotetext{
${ }^{14}$ James Wellford, interview with the author, New York, January 2014.
} 


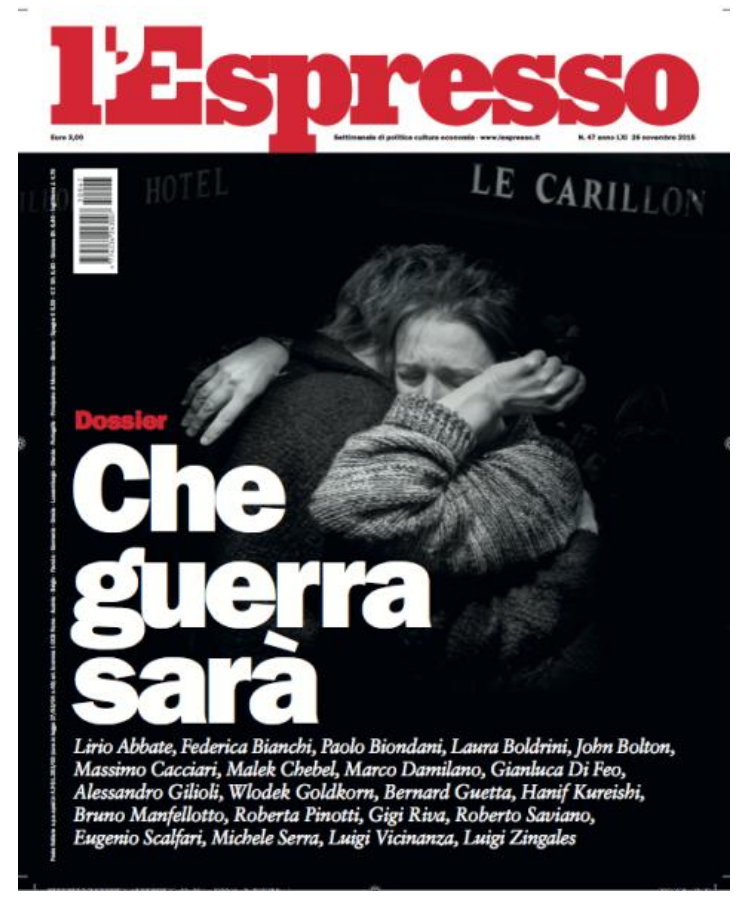

Fig. 10. "Che guerra sarà",

L'Espresso, November 26, 2015, cover image.

Photo by Alex Majoli (Magnum).

\section{Logics and reasons of consecration: Field effects and cultural legitimacy}

Recalling this paper's initial questions, how to explain the impressive process of global consecration of a restricted group of relatively young photojournalists coming mainly from scarcely institutionalized and peripheral national fields and in a historical phase of overall professional decline? As the previous photographs and interviews reveal, since the early 2000s, through a peculiar strategy of position-taking, a new generational group of photojournalists have questioned accepted conventions of practice and have rejected the historical orthodoxy of the field in favour of a more subjective statement. They refused to enter into the cycle of simple reproduction of the current norms and dominantly realistic modes of photojournalistic production. On the contrary, within a shift from "documentary" to so-called "emotional" photojournalism (Brennen 2010), they creatively developed new, expressionist and distinctive practices, which aimed at visually conveying not only "objective" news content but also "subjective" emotional interpretations as photojournalists qua authors. In so doing, they developed a process of progressive personalization and aestheticization of the photojournalistic practice, that turned out to represent a vehicle for the upward mobility of their status in the symbolic hierarchy of professional prestige. Not by chance, over the last few years, some of the photojournalists belonging to this elite have gradually entered the field of fine art, and their photographs have been sold within art galleries and exhibited within art museums (Morel 2006; Fried 2008; Colton 2009).

In stylistic terms, the struggle for consecration has increasingly taken the form of a struggle for distinction between more "realistic" and more "expressionistic" approaches to photojournalistic production. This is actually a structural distinction which has long been debated in the fields of photojournalism, photography and the visual arts (e.g. Kurasawa 2015) - and which could be fruitfully framed as a matter of field logics and boundaries. Today, in fact, professional photojournalists oppose amateur or "profane" forms of production through stylistic techniques that reveal and underline their role as authors, just like in the late 1800s impressionistic painters opposed photography - i.e. a practice imbued with realism, which was widely seen as "realer than painting" - by emphasizing those elements that could recall the spectators that their paintings were not a "record" or an imitation of reality, but an authorial "creation". In turn, photography's attempted 
promotion to the rank of art has often rested on at least a partial emancipation from technical constraints (Bourdieu 1990; Battani 1999), and "pictorialism" has often been strategically employed in photography as a device of "artification": already in the late Nineteenth century, photographers started departing from the conventions of "objective" representational clarity, while soft focus and blurred subjects were introduced to convey an artistic character to the photographs (Brunet 2012).

Since the 1970s photography has gradually entered the art world and it has increasingly been institutionalized as a form of high-brow art (Becker 1975; Fried 2008; Colton 2009; Brunet 2012). Since the 1990s, such a process has gradually involved also the subfield of photojournalism (Schwartz 1990), which had historically been defined in the previous decades by the logics of the news content rather than by the expression of artistic ambitions (Schwartz 1992; Zelizer 1995; Brennen 2010). ${ }^{15}$ Today the field boundaries between news photography and art photography are blurring (Rouillé 2005; Morel 2008) and they look "increasingly dependent on an audience's knowledge of a photographer's purpose, medium and context to distinguish between them" (Grenfell and Hardy 2007, 165).

At the same time, also the boundaries between professional and citizen/amateur photojournalism have been increasingly blurring since the early 2000s (Allan 2013). In reality, as this paper suggests, professional photojournalism was not only critically destabilized but also productively challenged by this shifting scenario. Photojournalists struggling for power have experimentally adjusted the existing standards of practice to the ongoing changes, in order to develop innovative strategies of field position-taking, to acquire higher consecration and public visibility, and - importantly - to eventually strengthen the symbolic boundaries between the professional-authorial and the unconsecrated (yet increasingly widespread) "citizen" forms of visual news production.

Over the last two decades, these two processes - the blurring of the boundaries between news photography and fine-art photography, as well as between professional and amateur/citizen photojournalism - have been deeply intertwined in a productive circle of field effects (see Fig. 4). In particular, the internal process of innovation and consecration represents the product of the meeting, or better the correspondence, between two relatively independent but overlapping phenomena: on the one hand, the competition for the audience among major newsmagazines, and the search for new visual languages and professionally productive opportunities among photojournalists (in an overall scenario of increasingly scarce and fragmented attention as well as professional, editorial and economic crisis); on the other hand, the necessity for professional photojournalists to distinguish themselves and reaffirm their status vis-à-vis the widespread diffusion of new accessible digital technologies and new non-professional visual news providers. ${ }^{16}$ Such a productive articulation of exigencies turned out to take shape in the upheaval in the internal hierarchy of the global photojournalistic field as well as in the wider transformation in the hierarchy of cultural legitimacy between the journalistic, photographic, and artistic fields - which in turn affects the structure of the photojournalistic field itself.

As a whole, this productive circle of field effects confirms Bourdieu's insight that "if the permanent struggles between possessors of specific capital and those who are still deprived of it constitute the motor of an incessant transformation of the supply of symbolic products, it remains true that they can only lead to deep transformations of the symbolic relations of force that result in the overthrowing of the hierarchy of genres, schools and authors when these struggles can draw support from external changes" (Bourdieu 1992, 127, emphasis added).

\footnotetext{
${ }^{15}$ Such a logics could be synthetized as follows: "When a shooter puts his or her name to a news photo, the act does not mean "this is my vision." Rather, it means "I was there when it happened." Were it the photographer's vision, it would not be news. It would be art." (Barnhurst and Nerone 1999, 91).

16 As Ritchin $(2013,48)$ recently argued, "If a billion persons with cellphone cameras have greater proximity to breaking news events as well as to quirkier manifestations of the human condition, then the photojournalist and documentary photographer, having lost their privileged societal perch, must rethink their approaches, both destabilized and liberated by this wrenching moment of shifting paradigms".
} 
In turn, the process of consecration of the transnational elite of professional photojournalists could crucially contribute to bar what Bourdieu defines "the short circuit", "the possibility of passing directly from what is produced in the social world to what is produced in the field" (Bourdieu 1992, 248) - that is, within the photojournalistic field, the possibility for the photographs taken by amateur or citizen photographers to be considered, valued, displayed and circulated at par with the photographs taken by professionals. In other words, the process of consecration shows how the relative autonomy of the field can be asserted in those photographs whose aesthetic shape and symbolic value are precisely derived from the history and structure of the field.

\section{Conclusions}

By drawing creatively on Bourdieu's work on photography, and neo-Bourdieusian research on field-theory and journalism, this paper developed the framework of the "global photojournalistic field", and empirically focused on the practices of production and the symbolic struggle for consecration within professional photojournalism. In theoretical terms, it shed light on the implications of micro-level social processes for meso-level cultural fields, the dynamics of symbolic boundary-making and crossing between different (sub)fields, the correlated shifting hierarchies of cultural legitimacy (see Fig. 4) - and perhaps most importantly, on the possible reconfiguration of field theory in global/transnational terms. As such, it provided a conceptual and empirical contribution to the growing scholarship not only, specifically, on the struggle for consecration in cultural fields (e.g. Cattani, Ferriani, Allison 2014), but also, more widely, on the practices and forms of global cultural production, professional/citizen journalism, and digital photography.

Following the analysis, a few insights and pieces of suggestion for future research paths might be offered. A crucial aspect to be further developed deals with the relationship between the struggle for consecration within the field and the struggle for the autonomy of the field itself. If, as Bourdieu (1992; 1993) argued, the consecration of specific producers and exemplary products within a cultural field contemporaneously grants potentially greater autonomy to the field as a whole, then the herein analyzed dynamics might have significant (field) effects also over the historical struggle for cultural autonomy and legitimation of professional photojournalism.

In fact, even if, on the one hand, the increasingly blurred boundaries between news photography and art photography can favour stylistic innovation and symbolic consecration, on the other hand they are constitutively characterized by a deeply structural ambivalence. The dynamic boundary-work can allow forms of appropriations from close fields, but at the same time it forces photojournalistic authors to confront on the specificities of their own practice: on the one hand, one finds a potentially problematic innovative hybridization; on the other hand, one is asked to define and emphasize what really distinguish one's own practice of cultural production from others.

From this perspective, distinctive authorship in the field of photojournalism could eventually become a source of renewed professionalism: for example, professionally consecrated photojournalistic authors could more easily exercise - and require - a higher degree of control over the production process (e.g. the newsroom workflow, the selection and paging of photographs, etc.). However, professionalism does not only imply defining conditions and rules of the occupational practice and exercising control over the production of (visual) news, but it also refers to a set of widely shared, foundational ethical standards (Waisbord 2013). As a cultural practice that is claiming legitimacy, photojournalism looks still stigmatized by the lacking of easily accessible and largely recognized cultural institutions responsible not only for teaching an historical body of knowledge - e.g. visual-cultural theory, technical and deontological rules, controversial cases, best practices, etc. - as part of the legitimate (journalistic) culture, but also for controlling, criticizing and sanctioning, that is, for those elements which are constitutive of the inherently public role of (visual) journalism in the late-modern society - even further in times of complex crises and shifting paradigms. 
As the above analyzed process of professional consecration finally suggests, since the early 2000s the cultural field of global photojournalism has been renewing its traditional practices and symbolic hierarchies to face a rapidly shifting (digital) visual news ecology, yet it might hardly evolve toward greater autonomy and legitimacy without institutionally and critically improving its self-reflexive dimension of practice.

\section{References}

Allan, S., 2013. Blurring boundaries: professional and citizen photojournalism in a digital age. In: Lister, M., (Ed.), The Photographic Image in Digital Culture. 2nd ed. Routledge, Milton Park, 183-200.

Allan, S., and Patrick, C., 2013. The camera as witness: The changing nature of photojournalism. In: Fowler-Watt, K. and Allan, S. (Eds.) Journalism: New Challenges. Centre for Journalism \& Communication Research, Bournemouth University, 162-182.

Andén-Papadopoulos, K., Pantti, M., (Eds.), 2011. Amateur Images and Global News. Intellect, Bristol.

Barnhurst, K. G., 1994. Photography as Culture: Reconsidering the History of U.S. Photojournalism. Medien und Zeit 9 (1), 17-24.

Barnhurst, K.G., and Nerone, J.C.,1999. The President is dead: American news photography and the new long journalism. In: Brennen, B., and Hardt, H. (Eds.), Picturing the Past. Media, History, and Photography. University of Illinois Press, Chicago, 60-92.

Battani, M., 1999. Organizational fields, cultural fields and art worlds: the early efforts to make photographs and make photographers in the 19th-century United States of America. Media, Culture \& Society 21 (5), 601-626.

Becker, H.S., 1975. Art photography in America. Journal of Communication 74 (4), 74-85.

Becker, H.S., 1995. Visual sociology, documentary photography and photojournalism: It's (almost) all a matter of context. Visual Sociology 10 (1-2), 5-14.

Benson, R., 1999. Field theory in comparative context: a new paradigm for media studies. Theory and Society 28 (3), 463-498.

Benson, R., 2004. Bringing the sociology of media back in. Political Communication 21 (3), 275292.

Benson, R., 2006. News media as a "journalistic field": what Bourdieu adds to new institutionalism, and vice versa. Political Communication 23 (2), 187-202.

Benson, R., 2013. Shaping Immigration News. A French-American Comparison. Cambridge University Press, Cambridge.

Benson, R., Neveu, E., (Eds.), 2005. Bourdieu and the Journalistic Field. Polity, Cambridge.

Berglez, P., 2013. Global Journalism. Peter Lang, New York.

Boltanski, L., 1965. La rhétorique de la figure. In: Bourdieu, P. (1965), 173-198.

Bourdieu, P., (Ed.), 1965. Un Art Moyen. Essai sur les usages sociaux de la photographie. Éditions de Minuit, Paris.

Bourdieu, P., 1975. The specificity of the scientific field and the social conditions of the progress of reason. Social Science Information 14 (6), 19-47.

Bourdieu, P., 1983. The field of cultural production, or: the economic world reversed. Poetics 12, 311-356.

Bourdieu, P., 1985. The market of symbolic goods. Poetics 14, 13-44.

Bourdieu, P., (Ed.), 1990. Photography: A Middle-Brow Art. Polity, Cambridge.

Bourdieu, P., 1993. The Field of Cultural Production. Columbia University Press, New York.

Bourdieu, P., (Ed.) 1994. L'emprise du journalisme (special issue). Actes de la recherche en sciences sociales 101-102.

Bourdieu, P., 1996. The Rules of Art. Genesis and Structure of the Literary Field. Stanford University Press, Stanford. 
Bourdieu, P., 1998. On Television. The New Press, New York.

Bourdieu, P., 2000. The political field, the social science field, and the journalistic field. In: Benson, R., Neveu, E. (2005), 29-47.

Bourdieu, P., 2012. Picturing Algeria. Columbia University Press, New York.

Brennen, B., 2010. Photojournalism: Historical Dimensions to Contemporary Debates. In: Allan, S.

(Ed.) The Routledge Companion to News and Journalism. Routledge, New York, 71-81.

Brighenti, A. M., 2010. Visibility in Social theory and Social Research. Palgrave, New York.

Brunet, F., 2012. La photographie, éternelle aspirant à l'art. In: Heinich, N., Shapiro, R., (Eds.), De l'artificatìon. Enquêtes sur le passage à l'art. Éditions de l'Ehess, Paris, 29-46.

Casanova, 2004. The World Republic of Letters. Harvard University Press, Cambridge.

Cattani, G., Ferriani, S., Allison, P.D., 2014. Insiders, outsiders, and the struggle for consecration in cultural fields: A core-periphery perspective. American Sociological Review 79 (2), 258-281.

Champagne, P., (Ed.), 2000. Le journalisme et l'économie (special issue). Actes de la recherche en sciences sociales 131-132.

Collins, R., 1998. The Sociology of Philosophies. A Global Theory of Intellectual Change. Harvard University Press, Cambridge.

Colton, C., 2009. Photograph as Contemporary Art. Thames \& Hudson, London.

Cookman, C., 2009. American Photojournalism. Motivations and Meanings. Northwestern University Press, Evanston.

Cottle, S., 2009. Global Crisis Reporting. Journalism in the Global Age. Open University Press, Maidenhead.

Couldry, N., 2003. Media meta-capital: extending the range of Bourdieu's field theory. Theory and Society 32, 653-677.

Dickinson, R., 2008. Studying the sociology of journalists: the journalistic field and the news world. Sociology Compass 2 (5), 1383-1399.

Elliott, A., Urry, J., 2010. Mobile Lives. Routledge, London.

English, J.F., 2005. The Economy of Prestige. Prizes, Awards, and the Circulation of Cultural Value. Harvard University Press, Cambridge.

Fried, M. 2008., Why photography matters as art as never before. Yale University Press, New Heaven.

Go, J. 2008. Global Fields and Imperial Forms: Field Theory and the British and American Empires. Sociological Theory 26 (3), 201-229.

Grenfell, M., Hardy, C., 2007. Art Rules. Pierre Bourdieu and the Visual Arts. Berg, Oxford.

Gürsel, Z.D., 2012. The politics of wire service photography: Infrastructures of representation in a digital newsroom. American Ethnologist 39 (1), 71-89.

Hall, S., 1973. The determination of news photographs. In: Cohen, S., Young, J., (Eds.), The Manufacture of News. Deviance, Social Problems and the Mass Media. Constable, London.

Hamilton, P., 1997. Representing the social: France and Frenchness in post-war humanist photography. In: Hall, S., (Ed.). Representation: Cultural Representations and Signifying Practices. Open University Press, Maidenhead.

Hariman, R., Lucaites, J.L. 2016. The Public Image. Photography and Civic Spectatorship. University of Chicago Press, Chicago.

Heilbron, J. 2014. The social sciences as an emerging global field. Current Sociology 62 (5), 685703.

Heinich, N., 2012. De la visibilité. Excellence et singularité en régime médiatique. Galllimard, Paris.

Hesmondhalgh, D., 2006. Bourdieu, media and cultural production. Media, Culture \& Society 28 (2), 211-231.

Hilgers, M., Mangez, E., (Eds.), 2015. Bourdieu's Theory of Social Fields. Routledge, London. Kuipers, G., 2011. Cultural globalization as the emergence of a transnational cultural field. Transnational television and national media landscapes in four European countries. American Behavioral Scientist 55 (5), 541-557. 
Kurasawa, F., 2015. How does humanitaria visuality work ? A conceptual toolkit for a sociology of iconic suffering. Sociologica 9 (1).

Lemieux, C., 2001. Une critique sans raison? L'approche bourdieusienne des médias et ses limites. In: Lahire, B., (Ed.), Le travail sociologique de Pierre Bourdieu. La Découverte/Poche, Paris.

Löffelholz, M., Weaver, D., (Eds.), 2008. Global Journalism Research. Theories, Methods, Findings, Future. Blackwell, Oxford.

Marlière, P., 1998. The rules of the journalistic field: Pierre Bourdieu's contribution to the sociology of the media. European Journal of Communication 13 (2), 219-234.

Miller, R., 1997. Magnum. Fifty Years at the Front Line of History. Grove, New York.

Morel, G., 2006. Le Photoreportage d'auteur. L'institution culturelle de la photographie en France depuis les années 1970. CNRS Éditions, Paris.

Morel, G., (Ed.), 2008. Photojournalisme et art contemporain. Les derniers tableaux. Éditions des archives contemporaines, Paris.

Neveu, E., 2007. Pierre Bourdieu: sociologist of media, or sociologist for media scholars? Journalism Studies 8 (2), 335-347.

Pogliano, A., 2015. Iconic Photographs in the Newsrooms: an Ethnography of Visual News-making in Italy and France. Sociologica 9 (1).

Rosenblum, B., 1978. Photographers at Work. A Sociology of Photographic Styles. Holmes \& Meier, New York.

Reich, Z. and Klein-Avraham, I., 2014. Textual DNA: the hindered authorship of photojournalists in the Western press. Journalism Practice 8 (5), 619-631.

Ritchin, F., 2013. Bending the frame. Photojournalism, Documentary, and the Citizen. Aperture, New York.

Robbins, D., 2009. Gazing at the colonial gaze: photographic observation and observations on photography based on a comparison between aspects of the work of Pierre Bourdieu and JeanClaude Passeron. Sociological Review 57 (3), 428-447.

Rose, G., 2010. Doing Family Photography. The Domestic, the Public, and the Politics of Sentiment. Ashgate, Farnham.

Rouillé, A., 2005. La photographie. Entre document et art contemporain. Gallimard, Paris.

Santoro, M., 2008. Putting Bourdieu in the global field. Sociologica 2 (2).

Santoro, M., 2011. From Bourdieu to cultural sociology. Cultural Sociology 5 (1), 3-23.

Sapiro, G., 2010. Globalization and cultural diversity in the book market: The case of literary translations in the US and in France. Poetics 38 (4), 419-439.

Sapiro, G., 2015. The world market of translation in the globalization era: Symbolic capital and cultural diversity in the publishing field. In: Hanquinet, L., Savage, M., (Eds.), Routledge International Handbook of the Sociology of Art and Culture, Routledge, London, 262-276.

Sassen, S., 2002. Locating cities in global circuits. Environment \& Urbanization 14 (1), 13-30.

Savage, M., 2013. Digital Fields, Networks and Capital: Sociology Beyond Structures and Fluids. In: Orton-Johnson, K., Prior, N., (Eds.), Digital Sociology. Critical Perspectives. Palgrave, New York, 139-149.

Savage, M. and Silva, E., 2013. Field Analysis in Cultural Sociology. Cultural Sociology 7 (2), 111 126.

Schwartz, D., 1990. On the line: Crossing institutional boundaries between photojournalism and photographic art. Visual Sociology 5 (2), 22-29.

Schwartz, D., 1992. To tell the truth: codes of objectivity in photojournalism. Communication 13 (2), 95-109.

Solaroli, M., 2015. Toward a new visual culture of the news: Professional photojournalism, digital post-production, and the symbolic struggle for distinction. Digital journalism 3 (4), 513-532.

Steinmetz, G., 2008. The colonial state as a social field. American Sociological Review 73 (4), 589612.

Thompson, J.B., 2005. Books in the Digital Age: The Transformation of Academic and Higher Education Publishing in Britain and the United States. Polity, Cambridge. 
Waisbord, S., 2013. Reinventing Professionalism: Journalism and News in Global Perspective. Polity, Cambridge.

Webster, F., 1980. The New Photography. Responsibility in Visual Communication. John Calder, London.

Zelizer, B. 1995. Words against images: Positioning newswork in the age of photography. In: Hardt, H., Brennen, B., (Eds.), News workers. Toward a History of the Rank and File. University of Minnesota Press, Minneapolis, 135-159.

Zelizer, B. 2005. Journalism through the camera's eye. In: Allan, S., (Ed.), Journalism: Critical Issues. Open University Press, Maidenhead, 167-176.

\author{
Author name and affiliation \\ Marco Solaroli \\ Department of Philosophy and Communication \\ University of Bologna \\ Via Azzo Gardino 23 \\ 40122 Bologna \\ Italy \\ Email: marco.solaroli@unibo.it
}

\title{
Bio
}

Marco Solaroli is a Research Fellow in the Department of Philosophy and Communication at the University of Bologna. His research interests lie in the fields of social and cultural theory, sociology of culture and media, digital cultural production, photojournalism and visual culture.

\section{Acknowledgements}

I deeply thank Rodney Benson for his insightful comments on a previous version of this paper, and Marco Santoro for the fertile intellectual exchanges on Bourdieu's cultural theory.

\section{Funding}

This work was partly supported by a Fulbright Research Scholar fellowship held at New York University in 2013-2014. 